\title{
The impact of the rise of using solar energy in GCC countries
}

\author{
N.W. Alnaser ${ }^{1, *}$ and W.E. Alnaser ${ }^{2}$ \\ ${ }^{1}$ Department of Architecture and Interior design, College of Engineering, University of Bahrain, Kingdom of Bahrain, Bahrain \\ 2 Department of Physics, College of Science, University of Bahrain, Kingdom of Bahrain, Bahrain
}

Accepted: 27 February 2019

\begin{abstract}
The research and the prototype projects in the GCC countries were in place since 1970's which first was started in Kuwait, followed by Saudi Arabia in the 1980's, United Arab Emirates in the 1990's, Bahrain, Oman and Qatar in 21 centuries. Now all GCC countries had conducted, relatively, large project in solar and wind energy, especially Kuwait (currently about $70 \mathrm{MW}$ among a plan of $2000 \mathrm{MW}$ by 2030), UAE (currently about 300 MW among a plan of 2500 MW by 2030) and Saudi Arabia (with an ambitious renewable energy target of $3450 \mathrm{MW}$ by 2020 with a further $6000 \mathrm{GW}$ envisioned by 2023 and to $200000 \mathrm{MW}$ by 2030). Such an acceleration in the use of solar and wind energy would have an impact. Major impacts are: (1) Major reduction in the solar electricity prices in the region; (2) More investors in renewable energy business; (3) Rise of innovative design of houses to utilize its structure in installation and integration of renewable energy devices; (4) Rise of many service and maintenance of solar technology companies; (5) Establishment of new academic programs and courses in solar and other renewable energy technologies in the higher education institute and technical organizations; (6) More concern and studies on disturbances to the main grid due to solar connection; (7) Major reduction in carbon footprint per capita in GCC countries; (8) Use of more efficient and low consumption household and industrial devices; (9) Boost in battery industry for solar electricity storage.
\end{abstract}

\section{Introduction}

GCC countries had the passion in using renewable energies since 1970's. This is no surprise for GCC countries, as it is blessed with an abundance solar energy, as the annual average solar radiation within the GCC countries is relatively equal to 1.1 barrel of oil equivalent per $\mathrm{m}^{2}$. The radiation is the highest in Kuwait, in June-July, $\left(8200 \mathrm{kWh} / \mathrm{m}^{2}\right)$ and the lowest in Oman $\left(6400 \mathrm{kWh} / \mathrm{m}^{2}\right)$. The radiation is low in January-December $\left(4200 \mathrm{kWh} / \mathrm{m}^{2}\right.$ in the UAE and $3200 \mathrm{kWh} / \mathrm{m}^{2}$ in Bahrain) [1]. The first large solar energy project in the region was in Kuwait (by Kuwait Institute for Scientific Research, KISR), followed by Saudi Arabia (by King Abdulaziz City for Science and Technology, KACST) in the 1980's, United Arab Emirates in the 1990's (by Masdar), Bahrain (by Bahrain Petroleum Company and now by the Sustainable Energy Unit SEU), Oman and Qatar in 21 centuries. Among these projects is the full solar air-conditioned school (The British School) in Kuwait using PV and solar thermal applications in 1970, full PV operated fuel filling station in Bahrain at Al Hora area in Manama, Bahrain, in 1980, The Solar Village PV system $350 \mathrm{~kW}(2155 \mathrm{MWh})$ to provide AC/DC electricity for remote areas from 1981 to 1987 [3].

\footnotetext{
* e-mail: nalnaser@uob.edu.bh
}

Now all GCC countries had conducted, relatively, large project in solar and wind energy, especially Kuwait (currently about $70 \mathrm{MW}$ among a plan of $2000 \mathrm{MW}$ by 2030), UAE (currently about $300 \mathrm{MW}$ among a plan of 2500 MW by 2030) and Saudi Arabia (with an ambitious renewable energy target of $3450 \mathrm{GW}$ by 2020 , with a further $6000 \mathrm{GW}$ envisioned by 2023 and to $200000 \mathrm{MW}$ by 2030). Table 1 sheds light on current large projects $[2,3]$. Figure 1 illustrates the current and future planned solar projects in the pipeline in the GCC countries [2]. However, it is thought that more major solar projects - at GW scalewill be announced officially, i.e. an installation of the world largest PV project (GW size) during the visit of the Chinese president to UAE in middle of July 2018. Currently, Saudi Arabia was in talks to develop the world's largest solar power plant in entering an agreement to develop a $\$ 200$ billion solar power plant, that's anticipated to be up and fully running by 2030 (200 GW) of solar power, which is approximately double the amount of solar energy produced globally last year and more than 100 times as large as the new next biggest solar plant project which would generate more than 100000 jobs [4].

The literature survey leads us to conclude that there is a great development of solar energy in GCC countries in accelerated steps without underpinning it with strategic policy development plans, which will surely have an impact. This paper is attempted explore these impacts. 
Table 1. Summary of solar PV development in the GCC countries [2].

\begin{tabular}{llllll}
\hline Country & $\begin{array}{l}\text { Solar energy target } \\
\text { share in total installed } \\
\text { capacity }\end{array}$ & $\begin{array}{l}\text { Primary } \\
\text { energy } \\
\text { sources }\end{array}$ & $\begin{array}{l}\text { Maximum } \\
\text { solar insolation } \\
\left(\mathrm{kWh} / \mathrm{m}^{2} / \text { year }\right)\end{array}$ & $\begin{array}{l}\text { Current } \\
\text { operational } \\
\text { solar projects }\end{array}$ & Future projects \\
\hline Bahrain & $\begin{array}{l}5 \% \text { of all renewable } \\
\text { including solar (2020) }\end{array}$ & Oil, gas & 2180 & $\begin{array}{l}0.5 \mathrm{MW} \text { solar plant at } \\
\text { the Bahrain University }\end{array}$ & $\begin{array}{l}5 \mathrm{MW} \text { solar project at } \\
\text { Al power and } \\
\text { water plant }\end{array}$ \\
& & & $\begin{array}{l}5 \mathrm{MWp} \text { Bapco pilot } \\
\text { plant }\end{array}$ &
\end{tabular}

Kuwait $\quad 1 \%$ in $2015,10 \%$ by $\quad$ Oil, gas 2200 2020 and $15 \%$ by 2030

UAE

$7 \%$ of all renewables by $2020,25 \% 2030$

and $75 \%$ by 2050

Qatar

$20 \%$ of all renewables

with solar

incorporated by 2030

and $15 \%$ solar by 2018

Oil, gas 2285

\section{Oil, gas 2113}

Oman $\quad 10 \%$ by $2020 \quad$ Oil, gas 2500

Kingdom of $54 \mathrm{GW}$ from

renewables including

solar technology

Oil, gas 2200
See Table 1 in reference [2]

See Table 2 in reference [2]

Establishment of solar PV manufacturing plant in Ras Lafin

See Section 3.5 in reference [2]
$50 \mathrm{MW}$ solar project across the country

1000 MW Mohammed bin Rashid $\mathrm{Al}$

Maktoum Solar Park

Stadiums with solar technology cooling for the football world Cup 2022; 1000 MW solar PV plant in Doha

$300 \mathrm{~kW}$ solar project at Al MazyonahDhofar; $1000 \mathrm{~kW}$ solar project in Haima, $28 \mathrm{~kW} \mathrm{PV}$ and storage system at Al MathfaDhofar; $100 \mathrm{~kW}$ PV in Hijji See Table 3 in reference $[2]$
$1000 \mathrm{MW}$ solar plant in Makkah; $10 \mathrm{MW}$ Al-Khafji plant; 1.8 MW King Abdullah Petroleum Studies and Research Centre

\section{Technical and strategical issue on solar technology utility}

Before involving in discussing the impact of the rise of using solar energy in GCC countries, it sounds better to highlight some technical and strategical issues on solar technology utility in these countries. These are the followings:

- currently, there are investments and plans to use solar energy in GCC countries that is gaining a momentum; however, the recent developments in the technology used for extracting gas and oil from shale rock formations places a big question mark on the GCC countries' energy plans including the use of renewable sources of energy [5];

- electricity demand in the region has been increasing at an annual rate of around $8 \%$-faster than the growth recorded in any other region of the world. It is estimated that over the next decade the GCC countries will need to add $100 \mathrm{GW}$ of additional power to support their economies, which are running at twice the growth rate of major advanced word economies [5];

- sustainable energy in GCC states has been considered since 2008. Resource effciency programs, clean technology research, alternative energy projects, green building codes, green economy strategies, and public transport systems have become a part of mainstream news. The GCC states have started to have a stake in the transition to sustainable energy and have already undertaken some policy, projects, and sector-wide efforts, which will boost the investment and its effect on the environment. However, many of these policies and plans are not actually enforced or imposed [6];

- the region is appropriate for PV and solar thermal applications on a large scale with little presence of clouds do not exceed only $20 \%$ of the year [6], which highly qualify these countries to use solar heating and cooling applica- 


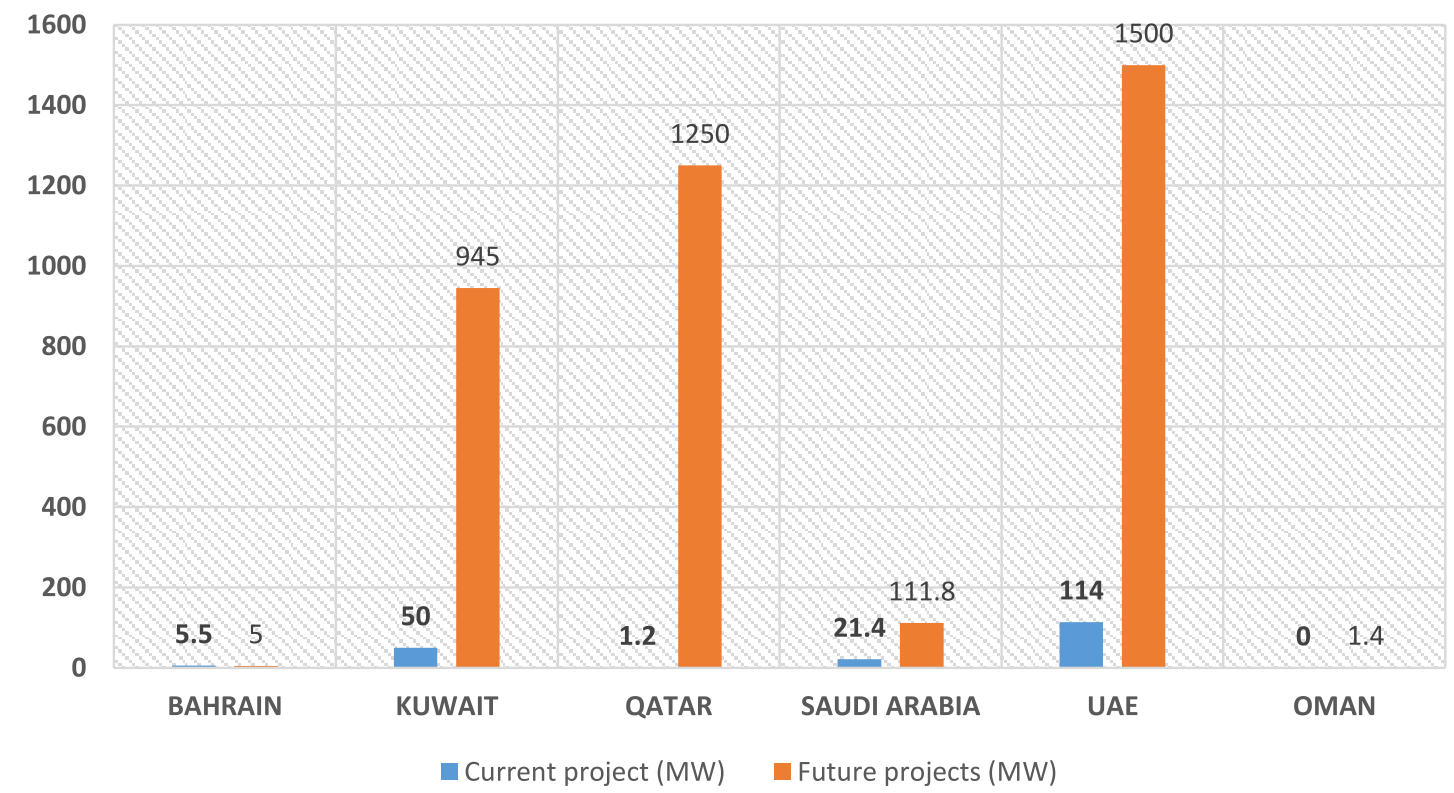

Fig. 1. Current and future planned solar projects in the pipeline in the GCC countries [2].

tions, Concentrated Solar Power (CSP) and PV applications since the global radiation is relatively high (from 1920 to $2450 \mathrm{kWh} / \mathrm{m}^{2} /$ year). The summer demand in the region is about $10.8 \mathrm{GW}$, and this demand supplied from combined-cycle turbines fueled with cheap legacy gas and expensive imported LNG. Using solar power plants can introduce about $3.5 \mathrm{GW}$ of nominal PV capacity and can be stored to overcome evening peak (10:00 to 11:00 pm), where thermal storage, energy storage (e.g. pumped storage where available), production of portable water at off-peak times and electricity trading with neighbors at irregular peak times can be utilized. These solutions have become economically attractive as they have less capital cost compared to gas turbines [7]. For this reason, GCC countries have launched a sense of the importance of converting part of its electrical energy produced by fossil fuels to alternative energies;

- the six GCC countries are located in an arid and solar zone. They occupy latitude $17^{\circ} \mathrm{N}$ to $32^{\circ} \mathrm{N}$ and longitude $35^{\circ} \mathrm{E}$ to $60^{\circ} \mathrm{E}$. The following information imposed itself for inclusion to allow comparison of technical, economic and policy issues between these countries:

- the mean yearly solar radiation in Bahrain is, approximately, $2180 \mathrm{kWh} / \mathrm{m}^{2}$ [1]. The share of RE in Bahrain is planned to reach between 5 and $7 \%$ from electricity power generating capacity by 2030 [8],

- Saudi Arabia has a yearly average solar radiation of $2200 \mathrm{kWh} / \mathrm{m}^{2}[9,10]$. Research and development activities show that solar energy has diverse practical applications in the KSA. The share of renewable energy is $30 \%$ Electricity generation,

- UAE has huge solar potentials with the mean annual solar radiation of $2285 \mathrm{kWh} / \mathrm{m}^{2}$ and average sunshine of $10 \mathrm{~h}$ per day $[11,12]$. However, high-humidity and dust particles in the atmosphere reduce the solar intensity [13]. However the government of the UAE had set a target of $7 \%$ energy mix by the year $2020,25 \%$ by 2030 and $75 \%$ by 2050 [14],
- Kuwait's annual solar radiation is predicted to be between 2100 and $2200 \mathrm{~kW} / \mathrm{m}^{2}$ [15]. The average daily sunshine hours/year for Kuwait range from 7 to 12 [16]. Kuwait plans to expand the share of $\mathrm{RE}$ in the country's energy mix by $1 \%$ in the year 2020 and up to $15 \%$ by 2030 [17];

- Oman has an annual solar radiation, varying from 2200 to $2500 \mathrm{kWh} / \mathrm{m}^{2}$ [18]. The highest solar radiation in Oman is in Marmul, followed by Fahud, Sohar and Qairoon Hairiti [19],

- Qatar is a country with abundant solar resources, reported to be up to $2113 \mathrm{kWh} / \mathrm{m}^{2} /$ year for the ground measured yearly average, calculated considering the 4 -year period of coincident data [20]. Studies show that the presence of high-ambient temperature in Qatar coupled with dusty conditions affect the performance and reliability of PV panels [21]. A recent study shows that Qatar solar potentials are equivalent to 1.5 million barrels of crude oil annually with an average sunshine hours in Qatar are 9.5 across the year [22];

- it had been reported that the drop in the output of the PV electricity (PVD), as a function of dust accumulation;

- measured as mass per unit area (ds) - which nearly applicable to all GCC countries can be calculated from the following relation [23]:

$$
\begin{aligned}
\operatorname{PVD}(\text { in } \%) & =\left(\mathrm{PV}_{\mathrm{d}} / \mathrm{PV}_{\text {nd }}\right)_{\mathrm{drop}} \\
& =100-99.66 \exp \left(-0.035 \mathrm{~d}_{\mathrm{s}}\right)
\end{aligned}
$$

where $\mathrm{PV}_{\mathrm{d}}$ is the output of the dusty and $\mathrm{PV}_{\mathrm{nd}}$ is the output of non-dusty (clean) PV.

The actual solar electricity gained from each $\mathrm{kW}$ installation of PV in GCC countries can be estimated from the following relation, which takes into consideration the dust accumulation and sky turbidity [24]: 
Table 2. PV installation in GCC countries with cost per solar Watt [25].

\begin{tabular}{|c|c|c|c|c|c|c|c|c|}
\hline & Project name & Location & $\begin{array}{l}\text { Type of } \\
\text { installations }\end{array}$ & $\begin{array}{l}\text { Capacity } \\
\text { (Max Peak } \\
\text { DC) }\end{array}$ & $\begin{array}{l}\text { Year } \\
\text { built }\end{array}$ & Cost & $\begin{array}{l}\text { Annual } \\
\text { generation }\end{array}$ & $\begin{array}{l}\text { Normalized } \\
\text { annual generation }\end{array}$ \\
\hline 1 & Masdar & Abu Dhabi, UAE & Ground Mount & $10 \mathrm{MWp}$ & 2009 & $\$ 5 / \mathrm{W}$ & $17.5 \mathrm{GWh}$ & $1.75 \mathrm{MWh} / \mathrm{MW}$ \\
\hline 2 & $\begin{array}{l}\text { KAUST Solar } \\
\text { Park }\end{array}$ & $\begin{array}{l}\text { KAUST Saudi } \\
\text { Arabia }\end{array}$ & Rooftop & $2 \mathrm{MWp}$ & 2010 & $\$ 7 / \mathrm{W}$ & $3.3 \mathrm{GWh}$ & $1.65 \mathrm{MWh} / \mathrm{MW}$ \\
\hline 3 & $\begin{array}{l}\text { Saudi Aramco } \\
\text { Solar Car Park }\end{array}$ & $\begin{array}{l}\text { Dhahran Saudi } \\
\text { Arabia }\end{array}$ & $\begin{array}{l}\text { Mixed (car park, } \\
\text { rooftop, } \\
\text { trees, pole mount) }\end{array}$ & $10.5 \mathrm{MWp}$ & 2012 & $\$ 10 / \mathrm{W}$ & $17.5 \mathrm{GWh}$ & $1.67 \mathrm{MWh} / \mathrm{MW}$ \\
\hline & $\begin{array}{l}\text { KAPSARC } \\
\text { Project-1 }\end{array}$ & $\begin{array}{l}\text { Riyadh Saudi } \\
\text { Arabia }\end{array}$ & Ground Mount & $3.5 \mathrm{MWp}$ & 2013 & $\$ 4.5 / \mathrm{W}$ & $5.8 \mathrm{GWh}$ & $1.66 \mathrm{MWh} / \mathrm{MW}$ \\
\hline 5 & $\begin{array}{l}\text { KAPSARC } \\
\text { Project-2 }\end{array}$ & $\begin{array}{l}\text { Riyadh Saudi } \\
\text { Arabia }\end{array}$ & Ground Mount & $1.8 \mathrm{MWp}$ & 2014 & $\$ 3.5 / \mathrm{W}$ & $2.9 \mathrm{GWh}$ & $1.61 \mathrm{MWh} / \mathrm{MW}$ \\
\hline 6 & $\begin{array}{l}\text { Kuwait oil } \\
\text { company }\end{array}$ & $\begin{array}{l}\text { Umm Gudair } \\
\text { Kuwait }\end{array}$ & Ground Mount & $5 \mathrm{MWp}$ & 2014 & $\$ 5.6 / \mathrm{W}$ & $8 \mathrm{MWh}$ & $1.68 \mathrm{MWh} / \mathrm{MW}$ \\
\hline 7 & $\begin{array}{l}\text { BAPCO pilot } \\
\text { project }\end{array}$ & BAPCO, Bahrain & $\begin{array}{l}\text { Mixed } \\
\text { (14 locations) }\end{array}$ & $5 \mathrm{MWp}$ & 2014 & $\$ 5 / \mathrm{W}$ & $8.3 \mathrm{GWh}$ & $1.66 \mathrm{MWh} / \mathrm{MW}$ \\
\hline 8 & TATWEER & Bahrain & Ground Mount & $1 \mathrm{MW}$ & 2016 & $\$ 1.5-1.8$ & $1.9 \mathrm{GWh}$ & $1.9 \mathrm{MWh} / \mathrm{MW}$ \\
\hline
\end{tabular}

Actual solar electricity produced in

$\mathrm{kWh}=$ Installed $\quad$ Power $($ in $\mathrm{kW}) \times 3.6 \times 365$,

while the maximum estimated solar electricity yield - which assumes a regularly cleaned PV and clear sky with no turbidity - can be estimated from the following relation:

The maximum estimated solar electricity produced in

$$
\mathrm{kWh}=\text { Installed Power }(\text { in } \mathrm{kW}) \times 4.6 \times 365 .
$$

The figures 2.8 and 4.6 are related to the system performance, which is related to PV efficiency, and its performance under warm-hot environment like GCC countries. Table 2 shows the PV Installation in GCC countries with cost per solar Watt. It clearly shows that each installed $\mathrm{kW}$ is expected to produce, annually, about $1650 \mathrm{kWh}$ of solar electricity, i.e. daily $4.5 \mathrm{kWh}$ [25].

Nearly all of the GCC countries have set relatively low prices of electrical energy unit $(\mathrm{kWh})$, not to encourage more energy consumption and waste but rather to assist the citizens in overcoming the harsh-hot and warm weather that nearly prevail for 7 months. Nearly $70 \%$ of household electricity is used for air conditioning. The temperature in GCC countries reaches up to $60^{\circ} \mathrm{C}$ (Kuwait) in mid-summer and relative humidity of about $75 \%$ like Bahrain and UAE. Its only few months where people in GCC countries do not use air condition.

In 2011, energy subsidies accounted for $15,32,28$, and $15 \%$ of all government expenditures, respectively in Kuwait, Saudi Arabia, the UAE, and Qatar. Since that time; however, the GCC region has been accelerating a trend to develop more open energy markets with less subsidies in order to ease the burden on government budgets already strained by the prolonged global oil price slump. The prices of electricity had increased from 2011 to now about 4-6 times.
The average cost of $\mathrm{kWh}$ in GCC countries is now $6 \mathrm{c} \$$, while in 2011 it was only $2 \mathrm{c} \$$ for residential, while for commercial it was $6 \mathrm{c} \$$ in 2011 and jumped now to $12 \mathrm{c} \$$ [26]; this is still much less than the tariff in USA (13c $\$ / \mathrm{kWh}$ ). The relatively low tariff for $\mathrm{kWh}$ in GCC countries is not an encouraging factor to install PV systems on rooftop to produce solar electricity. This price makes the payback period (PBP) too large (about 100 year for a $7 \mathrm{~kW}$ with cost of USD $3 / \mathrm{W}$ ). PBP can be easily estimated by using the following relation:

$$
\begin{aligned}
\mathrm{PBP}= & {[\text { cost of total PV system } /(\text { solar electricity }} \\
& \text { produced in } \mathrm{kWh} \times 3.0 \times 365)] .
\end{aligned}
$$

For example, in Bahrain, for a full $7 \mathrm{~kW}$ photovoltaic system the customer will pay USD 9100 (PV panels plus invertors and charge regulators). If the government purchase each $\mathrm{kWh}$ at a cost of $1 \mathrm{c} \$$ (3 fils) then the PBP will be 118 years, while if the tariff is purchased at a cost of $26 \mathrm{c} \$$ (100 fils) - if Feed-In-Tariff is initiated - the PBP will be 4.6 years. More accurate calculation of PBP can be made by referring to reference [27].

All GCC countries had signed the Kyoto Protocol and there acceleration in using solar and other renewable energy is driven mainly by their respect and obligations toward the climate change. The previous delay in using renewable energy at a large scale is attributed to lack of suffcient awareness, high capital cost, fear of moving from secure and conventional energy resources to uncertain and irregular clean renewable energy sources, lack of clear regulations and incentives, lack of industrial motivation, lack of expertise and know-how and lack of adequate of information about these new technologies [6,28].

The average electricity consumption per capita in GCC countries exceeds $10.000 \mathrm{kWh}$; this meanly due to harsh environment, lack of natural vegetation, lack of natural water, dusty nature of region, high solar radiation. All these 


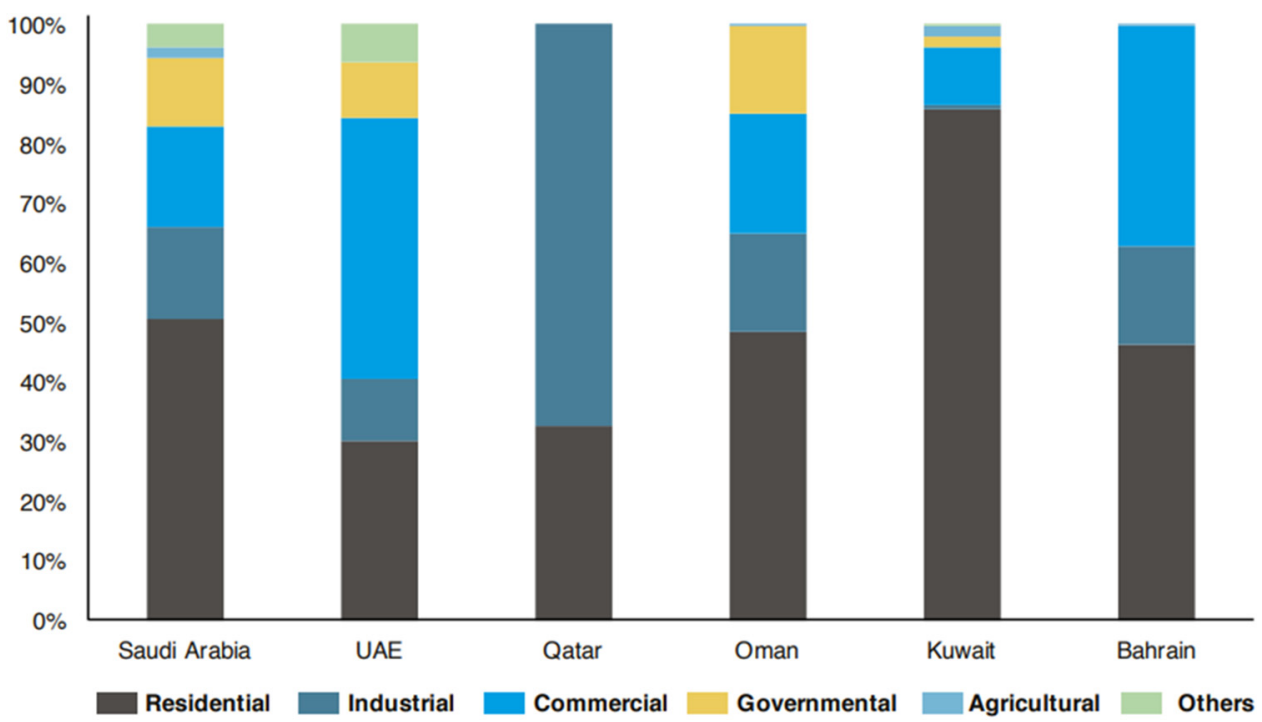

Fig. 2. Sectoral energy consumption in 2015 [30].

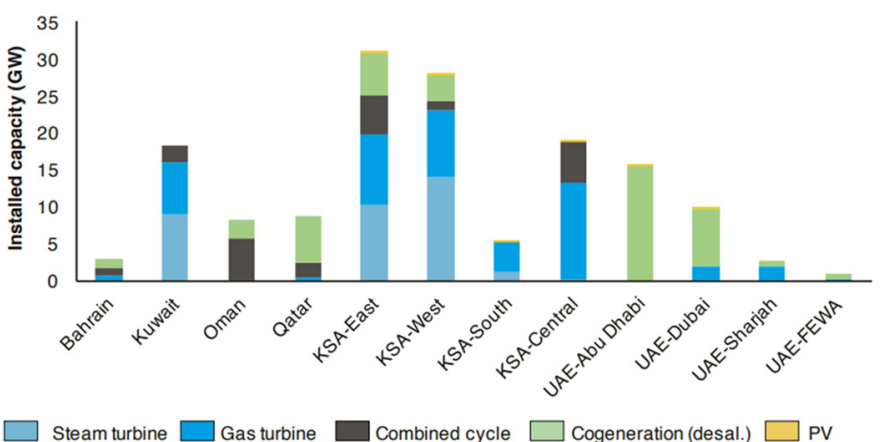

Fig. 3. Power and water capacity by technology type [31].

factors impose the GCC citizen to become heavily dependent to electricity utility, especially to air conditioning. Here comes the importance of investing and supporting research in solar cooling to make the cost of purchase of such devices affordable, reliable and low tariff; such product must be subsided initially; in similar manner of subsidizing the LED lights in China during its initial launching.

The electricity consumption per capita in Bahrain is $19592 \mathrm{kWh}\left(\mathrm{CO}_{2} /\right.$ capita $=23.4$ tons $)$, in Saudi Arabia is $9444 \mathrm{kWh} \quad\left(\mathrm{CO}_{2} /\right.$ capita $=19.5$ tons $), \quad$ Oman $6554 \mathrm{kWh}$ $\left(\mathrm{CO}_{2} /\right.$ capita $=15.4$ tons $)$, Qatar $15309 \mathrm{kWh}\left(\mathrm{CO}_{2} /\right.$ capita 45.4 tons $)$ UAE $11264 \mathrm{kWh} \quad\left(\mathrm{CO}_{2} /\right.$ capita $=23.3$ tons $)$, Kuwait $15213 \mathrm{kWh}\left(\mathrm{CO}_{2} /\right.$ capita 25.2 tons) and average world average is $3125 \mathrm{kWh}$ ( $\mathrm{CO}_{2} /$ capita 5.0 tons) [29]. It is very noticeable that the per capita consumption in Bahrain is very high which attributed to warm and humid weather - nearly throughout the year.

Figure 2 shows the sectoral energy consumption in 2015, which is assumed not has been changed much [30]. The GCC produced 1.17 billion tons of $\mathrm{CO}_{2}$-equivalent in 2012 [29]. The bulk of $\mathrm{CO}_{2}$-equivalent emissions in GCC are related to energy production and consumption with $95 \%$ of emissions are energy related, with agriculture, waste
Table 3. Electricity production in terawatt-hours (TWh), consumption (TWh) and peak load (GW) [32].

\begin{tabular}{lccc}
\hline Country & Production & Consumption & Peak load \\
\hline Bahrain & 14.1 & 12.6 & 2.9 \\
Kuwait & 68.3 & 60.5 & 12.8 \\
Oman & 31.3 & 31.3 & 6.1 \\
Qatar & 38.7 & 36.1 & 6.7 \\
Saudi Arabia & 304.2 & 274.5 & 56.6 \\
UAE-Abu Dhabi & 70.9 & 52.8 & 9.0 \\
UAE-Dubai & 39.6 & 38.4 & 7.2 \\
UAE-Sharjah & 5.7 & 10.2 & 2.2 \\
UAE-FEWA & 0.40 & 10.3 & 2.2 \\
Total GCC & 573.2 & 526.7 & \\
\hline
\end{tabular}

and land-use changes making up the remainder [31] and of this amount, the power and water sectors emitted 438 million tons of $\mathrm{CO}_{2}$-equivalent.

All GCC counties have a mix of power and water desalination capacity (Fig. 3) with Saudi Arabia, more than $80.5 \mathrm{GW}$ of power generation and UAE with the second-largest (almost $29 \mathrm{GW}$ ) while other countries have smaller capacities (Kuwait 18.3 GW, Qatar 8.6 GW, Oman 7.8 GW and Bahrain 2.8 GW [30].

GCC countries use large amount of electricity to produce desalinated water (about 16 million $\mathrm{m}^{3}$ per day) [32]. Notably, Bahrain, Oman and the three coastal regions of Saudi Arabia utilize RO technology. Kuwait and Qatar do not have any RO plants. A small number of thermal water-only plants, utilizing MED or MSF processes, exist in Kuwait and in the southern region of Saudi Arabia.

The magnitude of electrical production, consumption and peak loads is shown in Table 3 [30]. Saudi Arabia produces over half of all electricity in the GCC. 


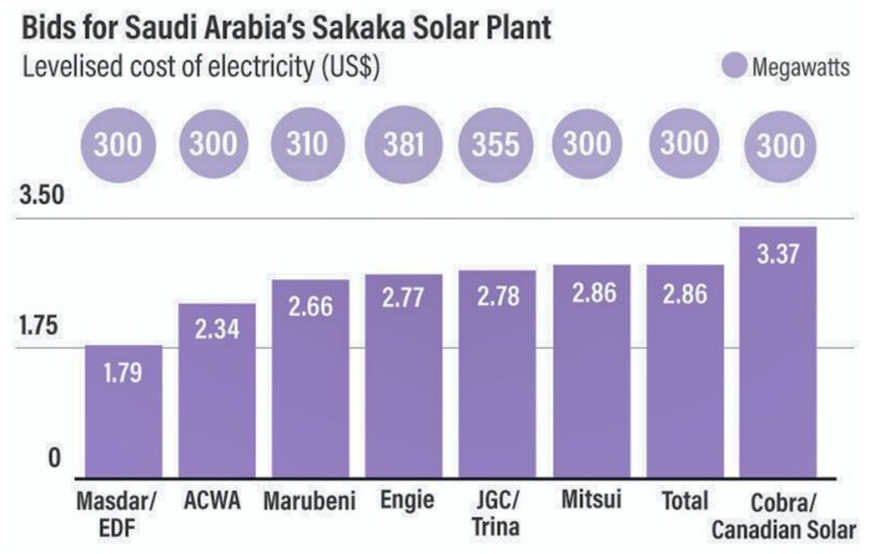

Fig. 4. Bid for Saudi Arabia Sakaka solar plant. It's a $300 \mathrm{MW}$ solar photovoltaic plant. The tarrif for each $\mathrm{kWh}$ solar is little as 6.7 halalas or 6.7 fils (or 1.79 cents) [34].

\section{The impact of the rise of using solar energy in GCC countries}

It has to be understood that GCC countries are of need to use renewable energy in general and in particular solar energy for many reasons. These are: a) vulnerable to the threat of rising sea levels; b) industrial areas are expanding; c) high annual energy demand growth rate, which ranges from 7 to $10 \%$; d) need of natural gas to meet its future energy demand; e) have very high solar radiation levels; f) set a Renewable Energy target in their vision 2030; g) need to open a green job; h) allow exchange of knowledge, technology and mutual cooperation. Such an accelerated use of solar energy after long slow maneuver to use this energy may have the following impacts:

\subsection{Major reduction in the solar electricity prices in the region}

The Renewable Energy Project Development Office's (REPDO) $300 \mathrm{MW}$ Sakaka project in Saudi Arabia reported the lowest PV LCOE (2.34 US\$ cents per $\mathrm{kWh}$ ) [33]. Also, Masdar and its French partner EDF submitted the lowest offer for the project at 1.79 US cents per kilowatt hour $(\mathrm{kWh})$ - as illustrated in Figure 4 [34]. The prices of PV panels had dropped from US $\$ 76$ to only US $\$ 0.3$ per Watt [35].

This drop in the prices is due to the availability of 100's of PV producers, offering more than 30 years warranty on PV panels, drops in solar system components. Table 4 lists the PV pipeline projects while Table 5 for CSP pipeline projects.

\subsection{More investors in renewable energy business}

GCC countries could reap multiple benefits from scaling up renewable energy use, including reducing water withdrawal by 11 trillion litres (or 16\%) and saving 400 billion barrels of oil in the power sector, creating 2000 direct jobs and reducing the region's per capita carbon footprint $8 \%$ by
2030 [36]. This will attract investors to further use solar energy, as they are witnessing this acceleration in executing major successful solar project with relatively low cost. This might encourage other developer in renewable energy to introduce themselves to GCC market and offer attractive prices and facilities.

Currently, China accounted for a record $45 \%$ of the global investment total, up from 35\% in 2016 followed by Europe (15\%), United States (14\%) Asia Oceania, excluding China and India, (11\%), Americas, excluding Brazil and the United States, (5\%), India (4\%), Middle East and Africa (4\%) and Brazil (2\%) [37]. In 2017, Solar $\mathrm{PV}$ and wind power had dominated the investment, accounting for roughly 57 and $38 \%$, respectively. Solar power was the only technology to witness an increase in 2017, with new investment up $18 \%$ relative to 2016 , to USD 161 billion. The investment in Middle East and Africa had increased by $11 \%$ in 2017, to USD 10.1 billion, with substantial increases in Egypt (USD 2.6 billion), and the United Arab Emirates (USD 2.2 billion) [37].

\subsection{Rise of innovative design of houses to utilize its structure in installation and integration of renewable energy devices}

The installation of PV systems on a rooftop - making the building integrated with Photovoltaic - for power up to $7 \mathrm{~kW}$ for a relatively low cost (BD 3500 or US\$ 9100) - such as in Bahrain - is an attractive, especially if: a) customer receives financial support or loan with minimal interest; b) the government buy the generated solar electricity from the rooftop with a generous cost (Feed-In-Tariff). This will encourage houses developers to make the roofs more fit to allow large utilization of the roof to account for PV installation with no obstacles. Currently, in GCC countries, the available roof area for PV panels is about $18 \%$ only for flats and $25 \%$ for villas in Khobar, Saudi Arabia $[38,39]$. Researchers in the GCC countries started to pay more attention for the houses design to account for possible integration with PV [40]. It might also take into consideration in making use of integration with other promising and brand new technologies renewable energy technology such as wind, geothermal, biofuels, biomass, and hydro [41].

It has to be noted that, it has been already reported the advantage and disadvantage of using the rooftop. It was the 9.6 PV installed on the rooftop, in a house in Greece, reduces the heat in the building in summer by $17.8 \%$ but requires more heating load in winter by $6.7 \%$ ! [42].

\subsection{Rise of many services and maintenance of solar technology companies}

Unfortunately, not all governments of the GCC countries had net metering facility, its only made in Bahrain. It is believed that with this accelerated use of solar energy utility, all GCC countries will introduce such a facility. Net Metering is a metering and billing arrangement designed to compensate distributed energy generation system owners for any generation that is exported to the utility grid. It 
Table 4. PV pipeline projects in Arab region [33].

\begin{tabular}{lllll}
\hline Country & Country & Capacity & Status & Client \\
\hline Bahrain PV & Bahrain & 200 & Announced & EWA \\
Solar IPP (West Nile) & Egypt & 600 & Prequalification & NREA \\
Solar IPP (KOM OMBO) & Egypt & 200 & Bid Stage & EETC \\
Round 3 & Jordan & 200 & Bid Stage & MEMR \\
Risha PV & Jordan & 50 & Financial Close & NEPCO \\
Water Authority Jordan & Jordan & 30 & Prequalification & Water Authority Jordan \\
KNPC & Kuwait & 1000 & Bid Stage & KNPC \\
NOOR MIDELT & Morocco & 800 & Bid Stage & MASEN \\
IBRI & Oman & 500 & Prequalification & OPWP \\
PDO-100MW & Oman & 100 & Prequalification & PDO \\
Qatar PV & Qatar & 200 & Announced & Kahramaa \\
Multiple Sites & Saudi Arabia & 6400 & Announced & RE PDO \\
Tunisia PV & Tunisia & 70 & Bid Stage & STEG \\
Tozeur PV & Tunisia & 10 & Bid Stage & STEG \\
Sweihanii & UAE & 1,200 & Announced & ADWEA \\
Dewa Phase V & UAE & 300 & Announced & DEWA \\
Total & 11860 & & & \\
\hline
\end{tabular}

Table 5. PV pipeline projects in Arab region [33].

\begin{tabular}{lllll}
\hline Country & Country & Capacity & Status & Client \\
\hline Taqa CSP & Egypt & 250 & Announced & TAQA Arabia \\
West Nile CSP & Egypt & 100 & Announced & \\
Lebanon CSP & Lebanon & 50 & Announced & \\
Noor Midelt & Morocco & 800 & Bid stage & MASEN \\
Total & & 1200 & & \\
\hline
\end{tabular}

allows residential and commercial customers who generate their own electricity from solar power to feed electricity they do not use back into the grid [43]. A more attractive facility in to have a Feed-In-Tariff that enables households to have a payback not more than 5 years. Unfortunately, no GCC countries had announce the Feed-In-Tariff facility; only UAE had offered what is called "Grants and subsidies" which is legislated from the Renewable Energy Deployment Strategy (2009, 2011, and last updated in 2015) [44]. Among Arab countries who have Feed-In-Tariff, are Egypt and Tunisia [44].

This means any interruption in PV system will lead to money loss and waste. This will lead to the birth and establishment of many maintenance or Energy Saving Companies (ESCo). This will create more green jobs and green economy. This rapid hop toward use of solar technology will encourage the investor to open business in this solar energy business including PV panels, Charge regulators (MPPT), PV aluminum frames and structure, PV auto cleaning using nanotechnology, AC/Dc invertors and promotion and media companies in such field.
The impacts of different renewable energy pathways on ecosystems and biodiversity, and the implications of these impacts for transitioning to a green economy have been discussed in detail elsewhere [45].

\subsection{Establishment of new academic programs and courses in solar and other renewable energy technologies in the higher education institute and technical organizations}

The accelerated use of solar technology in GCC countries will attract students to get registered in Science, Technology, Engineering and Mathematics (STEM). Universities and academia must prepare to such move and should align their programs with such a need. It will be an opportunity to establish long-term partnership between universities in GCC countries with the other international universities in science and innovation collaborations. This will lead to boost in faculty and student exchange program and flying professor program as well as condensed international courses and programs. It will also lead to 
working strategically with key stakeholders bilaterally across the world. This will foster closer people to people contacts in our shared interest in stability and prosperity.

It has to be noted that in USA, there is only 49 Bachelor's degrees programs in Sustainable Energy and 39 Sustainable Energy Master's degrees. In GCC countries, there is no single BSc in Renewable Energy or a diploma although a set of Renewable Energy education is proposed before 20 years through ISESCO by the current author [46].

Kandpal and Broman [47] had made a review of published literature (376 references) on renewable energy education initiatives across the globe, challenges faced, and potential approaches towards efficient and effective solutions as the 30 years, a large number of countries across the globe has initiated academic programs on renewable energy technologies and related aspects.

\subsection{More concern and studies on disturbances to the main grid due to solar connection}

One major reason for the fast dissemination of solar energy in the GCC countries, after long lag is due to many reasons among them is, renewable generation is made possible to connect to the grid, customers are made to receive incentives and are paid, appropriate deployment. Using solar electricity can be difficulty to steer accurately and can cause surges, i.e. very rapid growth over a few months then nothing for a while, which is difficult for the installers industry.

Network integration is an important issue that must receive great attention in opting for large and fast use of solar electricity. Electricity networks were designed for loads not generators. Therefore, power can flow backwards where networks do this naturally and do it very well [48]. Networks integration has the advantage of eliminating the need for batteries and the need for local balancing.

Voltage control is important when using solar electricity at a large scale because embedded generators cause voltage rise. In countries networks are short and wellengineered then this is not an issue otherwise it is significant (Saudi Arabia, Kuwait and UAE).

PV electricity (considered herein as Distributed Generators, DG) is normally designed to be grid-connected and not to Island. The reason is considered as DG, because the PV system is producing and distributing electrical power back into our utility grid. Therefore, Islanding refers to the condition of a DG generator that continues to feed the circuit with power, even after power from the electric utility grid has been cut off. Islanding can pose a dangerous threat to utility workers, who may not realize that a circuit is still "live" while attempting to work on the line [48]. Designing to allow islanding is expensive and unlikely to be justified with a reliable grid. Anti-islanding protection can lead to "block-tripping" which is bad for the grid. This risk can be reducing by careful choice of inverters and their settings and having fault ride-through capabilities. This is significant when there is large demand in solar electricity (more than $20 \%$ of the main installed conventional electricity of the grid). The conventional system relies on the rotating mass of all its conventional generators to provide inertia and keep the frequency steady at $50 \mathrm{~Hz}$ while PV electricity provides no inertia. This becomes a concern at high penetrations as once conventional is significantly reduced and taken off line. In fact operating low-inertia power systems is a current research challenge. Interconnector will help or expand the challenge [49].

The GCC countries should work hard from now to make their interconnection with solar electricity, have the following features [50]:

- prevent the penetration of the harmonics into the power grid;

- avoid the requirement of having controllable at the DC side of the power inverter;

- control the power factor level at the point of interconnection with the grid;

- relaxe the constraint of synchronizing the inverter output voltage with the power grid voltage;

- extract (if possible) maximum power from PVG panels.

\subsection{Major reduction in carbon footprint per capita in GCC countries}

According to Arab Petroleum Investments Corporation, the GCC countries represent $47 \%$ or $148 \mathrm{GW}$ of the current MENA power-generating capacity [51]. The harsh environment of GCC countries with natural water scarcity and the vision of the leaders of these nations for development and prosperity have led to a rise in the GCC's demand for energy. GCC countries would require US $\$ 85$ billion for the addition of $69 \mathrm{GW}$ of generating capacity and another US $\$ 52$ billion for T\&D over the next 5 years. The GCC power capacity needs to expand at an average annual pace of $8 \%$ between 2016 and 2020! Now assuming that if by year 2020 the solar electricity represents $5 \%$ of the installed electric power - which is $10.85 \mathrm{GW}$ out of $217 \mathrm{GW}$ - then the saved $\mathrm{CO}_{2}$ emission will be nearly 95 million tons! This means that from year 2020 to year 2030 the saved $\mathrm{CO}_{2}$ emission will be about 1 billion tons! This is a considerable amount if we know that GCC countries had produced 1.17 billion tons of $\mathrm{CO}_{2}$-equivalent in year 2012 [29]! This will make the carbon footprint less than the current. It has to be noted that carbon dioxide $\left(\mathrm{CO}_{2}\right)$ - Global energy-related $\mathrm{CO}_{2}$ emissions - grew by $1.4 \%$ in 2017, reaching a historic high of $32.5 \mathrm{Gt}$ [52]. The GCC countries emission may have reached about 1 Mtons.

\subsection{Use of more efficient and low consumption household and industrial devices}

Due to the future reliability on solar electricity for use in houses, building and industry in GCC countries, it is expected that consumers will only purchase low consumption and efficient appliances and devices since each $\mathrm{kW}$ of solar electricity offers maximum of $1680 \mathrm{kWh}$ (costing about US\$3000) annually while for this energy we need only $5732.4 \mathrm{ft}^{3}$ of natural gas which costs about US $\$ 7$ only (knowing that each $1000 \mathrm{ft}^{3}$ cost about US $\$ 4$. People will purchase 5 stars appliances. The air-conditions technology will witness great attention in GCC countries so that each 
thermal ton should consume less than $1 \mathrm{~kW}$ of electricity. A current air condition will operate for only $40 \mathrm{~min}$ if fed with $1 \mathrm{kWh}, 1 \mathrm{hr}$ for washing machine (rated $1 \mathrm{~kW}$ ), $125 \mathrm{hrs}$ for an 8 LED light [53]! Remarkable effort, business and investment will be on reducing the electricity consumption to make such appliance cope with the relatively expensive solar electricity.

\subsection{Boost in battery industry for solar electricity storage}

With the large dissemination and fast growth of solar electricity, which is sustainable and free (after the subsidized pay-back period) investors and developers will think seriously in standalone solar houses or premises or factories, especially, for rural but tourist attraction location. This will make them to invest solar electricity storage devices, in particularly batteries. The storage will be important to overcome the mismatch between the time of generation and demand, although in GCC countries the time difference is mostly just a few hours while in UK and Ireland are much larger [49]. Storing cold, either in the building fabric (concrete) or in ice (same water each day which not consuming water) will be also an option for cool air storage at night making use of the excess of solar electricity. This technology is a straight forward and proven low-cost. It is also of low value when gas powered, but will become very valuable.

In 2016, the first hints of a storage-driven transformation of the electricity business had come in Hawaii where Sunrun company offered their Brightbox product - a combination solar-plus-battery product - with a price of 19 cents per $\mathrm{kWh}$, which is almost $50 \%$ cheaper than grid electricity. By 2018, 1 in 5 new residential Sunrun solar customers in California was choosing to add storage [54]! The situation will be the same soon in GCC countries.

The prospects for solar plus storage are even more remarkable in the near future which is forecasted to witness steep declines in battery costs - by $50 \%$ in the next 5 years and by $70 \%$ by 2030. According to reports, batteries aren't just getting cheaper but will also reach far outstripping predictions. Bloomberg projected batteries crossing the US\$ 300 per $\mathrm{kWh}$ threshold in 2022 and will reach US $\$ 109 / \mathrm{kWh}$ in 2015 and further to as low as US $\$ 73 / \mathrm{kWh}$.

\section{Conclusion}

The fast and accelerated execution of large PV technology projects in GCC countries will have an impact in the region. Beside the reduction in the Carbon foot print and further cost of the solar W (low cost of $\mathrm{kWh}$ ) many new business will flourish such as battery storages for PV electricity, low power consumption air conditions and devices, boost in green job and green economy but policy makers must pay great attention to disturbance in interconnection to grids.

\section{References}

1. W.E. Alnaser, N.W. Alnaser, The status of renewable energy in the GCC countries, Renew. Sustain. Energy Rev. 15, 3074 (2011)

2. A.A. Mas'ud, A.V. Wirba, S.J. Alshammari, F.M. Sukki, M. M. Mu'azu Mohammed Abdullahi, R. Albarracín, M. ZiaulHoq, Solar energy potentials and benefits in the gulf cooperation council countries: A review of substantial issues, Energies 11, 372 (2018)

3. A. Hepbasli, Z. Alsuhaibani, A key review on present status and future directions of solar energy studies and applications in Saudi Arabia, Renew. Sustain. Energy Revi. 15, 502 (2011)

4. L. Stinson, Saudi Arabia is planning to build the world's largest solar power plant, Green Design News Apr 3, 2018. https://www.curbed.com/2018/4/3/17186292/saudi-ara bia-largest-solar-power-plant

5. N. Sultan, The challenge of shale to the post-oil dreams of the Arab Gulf, Energy Policy 60, 13 (2013)

6. H.M.S. Al-Maamary, H.A. Kazem, M.T. Chaichan, The impact of oil price fluctuations on common renewable energies in GCC countries, Renew. Sustain. Energy Rev. 75, 989 (2017)

7. S. Burger, The emerging opportunities in Saudi Arabia's solar market, GreenTechMedia.Com, March 5, 2013. https://www.greentechmedia.com/articles/read/saudi-so lar-plans \#gs.Khydd7hb

8. A. Al-Shalabi, N. Cotteret, E. Menichetti, EU-GCC cooperation in energy, in: S. Colombo (Eds.), Bridging the Gulf: EU-GCC relations at a crossroads, 2014, Edizioni Nuova Cultura, Roma, Italy, p. 357, ISBN: 8868122847

9. M.A. Salam, S.A. Khan, Transition towards sustainable energy production - A review of the progress for solar energy in Saudi Arabia, Energy Explor. Exploit. 36(1), 3 (2018)

10. S. Alyahya, M.A. Irfan, Analysis from the new solar radiation atlas for Saudi Arabia, Sol. Energy 130, 116 (2016).

11. A. Mokri, M.A. Ali, M. Emziane, Solar energy in the United Arab Emirates: A review, Renew. Sustain. Energy Rev. 28, $340(2013)$

12. A. Assi, M. Jama, M. Al-Shamisi, Prediction of global solar radiation in Abu Dhabi, ISRN Renew. Energy 2012, 1 (2012)

13. E. Zell, S. Gasim, S. Wilcox, S. Katamoura, T. Stoffel, H. Shibli, J. Engel-Cox, M.A. Subie, Assessment of solar radiation resources in Saudi Arabia, Sol. Energy 119, 422 (2015)

14. Masdar, UAE Projects, 2017. http://www.masdar.ae/en/ energy/uae-projects (accessed on 21 November 2017)

15. A.S. Alsharhan, Z.A. Rizk, A.E.M. Nairn, D.W. Bakhit, S.A. Alhajari, Hydrogeology of an Arid region: The Arabian Gulf and adjoining Areas (1st Ed.), Elsevier Science, Amsterdam, The Netherlands, 2001, ISBN: 9780080534329

16. A.Y. Al-Hasan, Electricity generation cost between proposed photovoltaic station and conventional units in Kuwait, Renew. Energy 12, 291 (1997)

17. International Energy Agency (IEA). Kuwait renewable energy target. https://www.iea.org/policiesandmeasures/ pams/kuwait/name-157557-en.php (accessed on 21 November 2017)

18. A.H. Al-Badi, A. Malik, A. Gastli, Sustainable energy usage in Oman-Opportunities and barriers, Renew. Sustain. Energy Rev. 15, 3780 (2011) 
19. A.H. Al-Badi, A. Malik, A. Gastli, Assessment of renewable energy resources potential in Oman and identification of barrier to their significant utilization, Renew. Sustain. Energy Rev. 13, 2734 (2009)

20. D. Bachour, Perez-Astudillo, D. Ground, Measurement GHI map for Qatar, Energy Procedia 49, 2297 (2013)

21. D. Martinez-Plaza, A. Abdallah, B.W. Figgis, T. Mirza, Performance improvement techniques for photovoltaic systems in Qatar: Results of first year of outdoor exposure, Energy Procedia 77, 386 (2015)

22. Energy Research Centre of the Netherlands (ECN). Private sector engagement-Qatar case study, in: NDE Workshop Yerevan, ECN: Petten, The Netherlands, 2015, pp. 1-14

23. N.W. Alnaser, A.A. Dakhel, M.J. Al Othman, I. Batarseh, J. K.S. Lee Najmaii, W.E. Alnaser, Dust accumulation study on the Bapco 0.5 $\mathrm{MW}_{\mathrm{p}} \mathrm{PV}$ project at University of Bahrain, Int. J. Power Renew. Energy Syst. 2(1), 39 (2015)

24. N.W. Alnaser, First Smart $8.64 \mathrm{~kW}$ BIPV in a building in Awali town at Kingdom of Bahrain, Renew. Sustain. Energy Rev. 82, 205 (2017)

25. W.E. Alnaser, N.W. Alnaser, I. Batarseh, Bahrain's BAPCO $5 \mathrm{MWp}$ PV grid-connected solar project, Int. J. Power Renew. Energy Syst. 1(2), 72 (2014)

26. http://cebcmena.com/wp-content/uploads/2018/03/CEBCEnergy-Efficiency-in-the-GCC-January-2018-REV2.pdf

27. S. Haji, A. Durazi, Y. Al-Alawi, Feed-in tariff structure development for photovoltaic electricity and the associated benefits for the Kingdom of Bahrain, Int. J. Sustain. Energy 37(5), 2018

28. EPIA (European Photovoltaic Industry Association). Glopal market outlook forphotovoltaics until 2016, 2012 http:// www.pv-magazine.com/fileadmin/uploads/PDFs/Global Market_Outlook_2016.pdf

29. The World Bank, World Development Indicators: Power and communications. http://wdi.worldbank.org/table/5.11

30. D. Wogan, S. Pradhan, S. Albardi, GCC energy system overview - 2017, October 2017/KS-2017-MP04, King Abdullah Petroleum Studies and Research Center (KAPSARC), 2017. https://www.kapsarc.org/wp-content/uploads/2017/ 11/KS-2017-MP04-GCC-Energy-Overview-2017.pdf

31. WRI (World Resources Institute), 2015. "CAIT Climate Data Explorer." http://www.wri.org/resources/data-visual izations/cait-climate-data-explorer

32. D. Wogan, S. Pradhan, S. Albardi, GCC energy system overview-2017, The King Abdullah Petroleum Studies and Research Center (KAPSARC), October 2017 / KS-2017MP04, Riyadh, Saudi Arabia, 2017. https://www.kapsarc. org/wp-content/uploads/7192017/11/KS-2017-MP04GCC-Energy-Overview-2017.pdf72033.33.

33. K. Duggal, Prominent Mesia Member Companies (PMMC), Solar outlook report 2018, Published by Middle East Solar Industry Association, Dubai, UAE, 2018. https://wwwme sia.com/wp-content/uploads/2018/03/MESIA-OUT LOOK-2018-Report-7March2018.pdf

34. M. Bernetti, World's cheapest prices submitted for Saudi Arabia's first solar project, The national, October 9, 2017. https://www.thenational.ae/business/energy/world-s-cheap est-prices-submitted-for-saudi-arabia-s-first-solar-proj ect1.663842

35. R. Fassbind, Price history of silicon PV cells since 1977, scalable vector graphics (SVG), 2017. https://commons. wikimedia.org/wiki/File:Price_history_of_silicon_PV_ cells_since_1977.svg
36. R. Ferroukhi, A. Arslan Khalid, D. Hawila, D. Divyam Nagpal, L. El-Katiri, V. Fthenakis, A. Al-Fara, Renewable energy market analysis: The GCC region, International Renewenable. Energy Agency (IRENA) Publication, UAE, 2016. http://irena.org/publications/2016/Jan/RenewableEnergy-Market-Analysis-The-GCC-Region

37. Renewables 2018 global status report, Renewable Energy Policy Network for the 21st century, 2018. http://www. ren21.net/wp-content/uploads/2018/06/178652 GSR2018_FullReport_web_final_.pdf

38. M. Asif, Prospects of building rooftop Application of solar pv in gcc countries, Solar Utility Network Conference, 7th Feb 2018, Bahrain International Exhibition Centre, Kingdom of Bahrain, 2018

39. M.M.A. Khan, M. Asif, E. Stach, Rooftop PV potential in the residential sector of the Kingdom of Saudi Arabia, Buildings 7(2), 46 (2017)

40. S.A. Al-Ghamdi, K.A. Alshaibani, The potential of solar energy in Saudi Arabia: The residential sector, J. Eng. Architect. 5(2), 32 (2017)

41. M. Arif, A. Hussain, M. Aslam, Emerging renewable and sustainable energy technologies: State of the art, Renew. Sustain. Energy Rev. 71, 12 (2017)

42. V. Kapsalis, D. Karamanis, On the effect of roof added photovoltaics on building's energy demand, Energy Build. 108, 195 (2015)

43. A. Al-Samahiji, Net metering policy and wind power opportunity SEU Solar energy engineer, Water and energy sustainable innovation and industry-WESII 2018, 22-23 April 2018, University of Bahrain, Kingdom of Bahrain, 2018. http://wesii.uob.edu.bh/images/Presentations/Netmeter ingpolicyandwindpoweropportunity.pdf

44. Y. Atalay, A. Kalfagianni, P. Pattberg, Renewable energy support mechanisms in the Gulf cooperation council states: Analyzing the feasibility of Feed-In-Tariff and auction mechanisms, Renew.Sustain. Energy Rev. 72, 723 (2017)

45. N.H. Alexandros Gasparatos Doll, M. Esteban, A. Ahmed, T. A. Olang, Renewable energy and biodiversity: Implications for transitioning to a green economy, Renew. Sustain. Energy Rev. 70, 161 (2017)

46. W.E. Alnaser, A. Al-kalak, M.A.T. Al-azraq, The efforts of the Arab League for Education, Culture and Scientific Organization (ALECSO) in the field of renewable energy, Renew. Energy 6(5-6), 649 (1991)

47. T.C. Kandpal, L. Broman, Renewable energy education: A global status review, Renew. Sustain. Energy Rev. 34, 300 (2014)

48. Wholesale Solar Team, What is Anti-Islanding?, Wholesale Solar Company, Northern California, 2019. https://www. wholesalesolar.com/solar-information/anti-islanding

49. M. Thomson, Integration of renewable energy in Bahrain, Water and energy sustainable innovation and industry Conference, University of Bahrain, April 2018, Kingdom of Bahrain, 2018

50. M. Taleb, F. Al Salam, F. Saleh, N. Mohamed, A grid connected photovoltaic system based on current conditioning, Water and energy sustainable innovation and industry Conference, University of Bahrain, April 2018, Kingdom of Bahrain, 2018

51. Ventures onsite for middle east electricity (2017) Gcc Power Market Report 2017, Ventures onsite publication, Middle East and North Africa project traker. https://www.mid 
dleeastelectricity.com/content/dam/Informa/Middle-EastElectricity/en/pdf/GCC\%20Power\%20Market\%20Report\% 20-\%20Oct17.pdf

52. International Energy Agency (IEA), Global Energy \& CO2 Status Report 2017, OECD/IEA 2018, March 2018. https://www.iea.org/publications/freepublications/publi cation/GECO2017.pdf
53. The Electricity Company of Ghana, Energy Saving Tips, Ghana, 2016. http://www.ecgonline.info/index.php/custom er-care/infocenter/energy-saving-tips.html

54. J. Farrell, Reverse power flow: How solar + batteries shift electric grid decision making from utilities to consumers, Institute for Local Self-Reliance, 17 Jul 2018. https://ilsr. org/solar-plus-storage/

Cite this article as: N.W. Alnaser, W.E. Alnaser, The impact of the rise of using solar energy in GCC countries, Renew. Energy Environ. Sustain. 4, 7 (2019) 